\title{
The Question of Shari'a and Human Rights
}

\author{
Rocio Daga Portillo
}

"The Universal Declaration of Human Rights opens up to the hope of a universal juridical order. This is one of the great contemporary debates and should not be engaged in with an approach of conquest or colonization but in line with reason (...) Humanity should be seen as one."1

The theme of this paper is not aimed at exposing crimes against human rights that could take place in countries where Shari'a is in one way or the other applied. It is not intended to be an assessment on the compatibility of Islam and human rights. Indeed it is no more than a reflection of conflicting points of Shari'a and human rights from a historical perspective and under the light of modern reforms and changes in the legal system, that have taken place during the last centuries in Islamic countries. It is important to notice that Muslims, willingly or not have gone through a period of secularization and influence by modern Western thought and laws in modern times.

How much the actual changes in society could influence reforms of Shari'a, remains to be seen. As a matter of fact, every country has its own history and has been confronted with modernity in a different way. One has to differentiate among westernized countries in North Africa and the Middle East from those less permeated by Western culture, like the Gulf countries, Pakistan or Afghanistan.

Classical Shari'a and reformed Shari'a of modern times are to be pondered from the perspective of human rights. Both systems of rights and duties that of Shari'a and that of human rights, have a different origin and foundation. However, the question on Shari'a and human rights has been raised by scholars, Western and Muslims, not only at a political level but also at a theoretical one. Nonetheless, the first question to be made here is, perhaps, the most problematic one:

What is Shari'a?

\section{What is Shari'a?}

Literally it could be translated as "the path to the source of water".

Shari'a is a way of life, Muslims say, and not a set of laws, least of all, of codified laws. It is the path to be followed to overcome the tests set by God in life, so that man exercises his capacity to reach Paradise. The law of God is like a propaedeutic that helps people and society to reach the state of perfection and the rewards in the afterlife. Since there is no conception of original sin and nature is not wounded in itself, the way of perfection is to fulfill the path established by Shari'a. Man has the capacity if he submits himself to the will of God and his law.

1 Jean-Marie Lustiger, "Citizen, Community, State. Towards a Critique of Modern Reason” in Oasis, 12, 2010, p.13. 
Shari'a includes all aspects of life. It consists of religious cult, ethics, as well as positive laws. It includes family, property, commerce, inheritance laws, social organization, war and peace, relation with non-Muslims and political order.

Hence, Shari'a is the framework for objective values for the majority of people in Islamic countries. Although, it must be pointed out that the realm of morals does not belong to the domain of individuals in Islam. Morals are a matter often controlled by the state. In the case of an Islamic state, morals would be controlled and sanctioned by a police institution, with its origin in medieval Islam, the Hisba.

At any rate, Shari'a being the source of morality in these societies, it is seen by Muslims as the alternative to the moral decadence of western societies.

On the other hand, Shari'a as a foundation for political and social organization is mainly used as an ideology by different political groups.

The question of Shari'a becomes complicated, indeed, since it includes a just demand by many people of sustaining identity, tradition and values. However, as a legalist tradition, and one without the possibility of questioning or reflecting on itself on philosophical grounds as well as in its historical context, Shari'a, became a set of rules, that cannot be question, concerned with what should be prohibited and allowed, alharam wa-l-halal. Nonetheless, this cannot possibly be the answer to the real demands and problems of people in a changing and globalized world. The question what is Truth, Justice and Good has to be made by individuals and groups beyond any political interest within their own religious tradition and inquiring by the means of reason.

Moreover, Shari'a might be defined as the hermeneutic of the will of God. Shari'a is not considered to be the revelation of God's essence or revelation of himself, but the revelation of his will. The will of God is to be found in the Koran and Sunna/ Hadith, the transmitted words and deeds of Muhammad.

Revelation in Islam does not take place in history of mankind. It does not happen through the experience of a people, like that of Israel and the life of those called upon by God, the Prophets. There is no conception of a history of salvation. Revelation had been given directly, dictated, by God to the Prophets. A God incarnated in history, who remains among his people in his instituted Church as the Emmanuel, God among us, and the Lord of History is even more unconceivable. God is completely separated from his creation.

According to Muslims, the final revelation was given to Muhammad. Jews and Christians have falsified the previous revelation given to mankind. Islamic revelation was given or dictated by God through an angel to Muhammad after he had been elevated into the world of angels. Thereafter, Muhammad would articulate it in the Arabic language. The words in the Koran are the literal words of God written down in Arabic. The Arabic language has in this sense an ontological value.

The way revelation takes place, coming directly from God and written down in Arabic in the Koran, has implications for the interpretation or hermeneutic of Koran. The Koran contains around 500 verses, with a content related to cultic prescriptions and laws of social organization for the community of Muslims, the Umma. The interpreta- 
tion of these verses is done basically on a philological basis without a critical historical method. The Koran is not be interpreted in a historical context.

The Sunna or Hadith, the second source of revelation, completes the revelation of Koran. Sunna, at the beginning an oral tradition, had been written down in the $9^{\text {th }}$ century and established as canonical works in six compilations or books, with the most important ones being those of al-Bukhari and Muslim.

In pre-Islamic Arabia, Sunna used to be understood as the imitation of a virtuous predecessor. In the Islamic period, it became to mean the imitation of Muhammad, the most virtuous predecessor of all times past and to come. "At an early period the ancient Arab idea of sunna, precedent or normative custom, reasserted itself in Islam. The Arabs were, and are, bound by tradition and precedent. Whatever was customary was right and proper; whatever the forefathers had done deserved to be imitated."2

But "Sunna in its Islamic context originally had a political rather than a legal connotation; it referred to the policy and administration of the Caliph. The question whether the administrative acts of the first two Caliphs, Abu Bakr and 'Umar, should be regarded as binding precedents, arising probably at the time when a successor to 'Umar had to be appointed, and the discontent with the policy of the third Caliph (...) took the form of a charge that he, in his turn, had diverged from the policy of his predecessors and, implicitly, from the Koran. In this connection, there appeared the concept of the sunna of the Prophet, not yet identify with a set of positive rules but providing a doctrinal link between the sunna of Abu Bakr and 'Umar and the Koran."3

Sunna or hadith came to mean, at some point, the words and deeds of Muhammad. Shafi'i, the engineer of Islamic law, established this tradition of hadiths-whose real origin may be found in customary law and the practice of the first caliphs- as Sunna of the Prophet. While Malik still follows customary law of Medina and takes as a model the actions of Muhammad's companions, Schafi'i defines the methodology of Islamic law and established as the second source of law the Sunna of the Prophet in form of hadith. ${ }^{4}$ An oral tradition, written down in the $9^{\text {th }}$ century, became a binding source of Law, only second in importance to the Koran.

The opposite of sunna would be innovation, bid'ah, which is considered as a synonym for heresy. In other words: "Sunna presents an obstacle to every innovation"5, J.Schacht affirmed.

Western scholars have stated that hadith is the practice of the Umayyad ascribed in retrospective to Muhammad containing elements of Arabic customary law, Jews and Roman law. For their part, Muslim experts on Islamic Law do not do question the origin of the hadith, taking them literally as the words and deeds of Muhammad. The science of hadith cultivated by Muslims scholars and ulemas consists in the study of the

2 J. Schacht, An Introduction to Islamic Law, Oxford University Press, Oxford, 1964, p. 17.

3 J. Schacht, An Introduction to Islamic Law, pp. 17-8.

${ }^{4}$ J. Schacht, The Origin of Muhammadan Jurisprudence, Oxford, 1950, pp. 24,73, 77.

5 J. Schacht, An Introduction to Islamic Law, p. 17 
chain of transmission and content, which provides the criteria to evaluate each hadiths and establish their juridical/theological weight as a source of revelation. ${ }^{6}$

\section{The system of deriving the Law, Fiqh.}

The way Islamic law or Shari'a adopted a system to derive the law, which constitutes the so-called fiqh, was not without controversy. This controversy takes place in the midst of political events and is influenced by political power. The period of formation coincides with the consolidation of the Islamic Empire, from the $8^{\text {th }}$ century to the $10^{\text {th }}$ century.

During the period of the $8^{\text {th }}$ century to the $10^{\text {th }}$ century, there were two contending trends of thought, a rationalist one, mu'tazilah, and that of Ibn Hanbal, which defends the transmitted sunna or hadith as the second source of revelation, after the Koran and against any rationalistic method applied to the Koran.

Shafi'i and later al-Ash' ari will find a middle way. Hadith/sunna obtains the status of canonization and elements of the rationalistic method incorporated, i.e. analogy.

At that point the science of fiqh or the basic principles of figh, usul al-fiqh, were laid down. From now on the method of finding out the will of God or the law of God would follow a certain methodology. "Legal reasoning", ijtihad, was established as a method in Shari'a, with subsequent figures of legal reasoning. Shafi'i established the method of legal reasoning as follows?:

Law must be derived from the Koran and Sunna, the foundation of law and first sources of law. They never contradict each other but complement each other.

The result of legal reasoning for later derivations of the Law cannot contradict the first sources of Law. A legal rule derived from clear text in the Koran and/or widely transmitted hadith is certain and no subject to disagreement.

Whatever cannot be found in Koran and Sunna, it will be found in consensus of the first virtuous generation or consensus of the experts in law, the 'ulama'.

The following step, in the event nothing is found in the previous sources, would be to apply analogy, qiyas, and other juridical concepts, like juridical preference, (istihsan) - although istihsan is not accepted by Shafi'i, only by the other schools of law -; welfare, (maslaha) necessity, (darura)and custom, ('urf, 'ada). Each school of law would put particular emphasis on one or another juridical concept for its methodology of deriving the law.

All of these concepts in a given hierarchy comprehend the methodology used by jurists and 'ulama' in order to derive Islamic law from the Koran and Sunna.

A rule derived from legal reasoning and analogy may be subject to disagreement, which it is a recognized juridical institution in Islam, ikhtilaf. In this way, we find in Shari'a a juridical figure that allows calling Shari'a a plural and flexible system within the untestable framework of Koran and Sunna. The category of ikhtilaf permits the

${ }^{6}$ M. Rohe, Das Islamische Recht, C. H. Beck, Münich, 2009, pp. 54-55.

7 W. b. Hallaq, Islamic Legal Theory, Cambridge University Press, Cambridge, 1997, p. 30. 
differences in legal opinion between the 'ulama'. This will constitute the basis for the creation of the four legal schools of law and a wide basis for incorporating customary law of conquered people. Traditionally is said, "ikhtilaf is mercy", rahma.

On the other hand, modern Muslims believe in the flexibility of the Shari'a, urging for the abolition of fiqh as a product of man's mind. However, the conflicting points of Shari'a law are found already in the Koran and Sunna. Therefore the problematic begins with the hermeneutic of these texts, not mentioning that texts from the Koran and Sunna are hardly interpreted in their historical context, while possessing a normative value. As a matter of fact, the strictest school of law that of the hanbalis, relies only on the Koran and Sunna and not in derived jurisprudence, fiqh.

The schools of law with its juridical method of legal reasoning and tenets remained unchanged since the $10^{\text {th }}$ century, until the Islamic world was impelled to introduce reforms and changes as a result of the encounter of Islamic civilization with the West in $18^{\text {th }}$.c.and $19^{\text {th }}$.c. Shari'a law is a law based on precedents and is not codified. In modern times, Shari'a had been submitted to a process of codification, taking the form of positive law. This codification, according to complains from Muslims, has introduced a major inflexibility in Shari'a. The question is where the real root of inflexibility is.

From the $19^{\text {th }}$ century through the middle of the $20^{\text {th }}$ century, enormous reforms were introduced in many fields of culture and law. Already since the exploration of Napoleon in Egypt, the eyes of the Ottoman rulers were blinded by the technical achievements of the West. Thus, the period of Tanzimats or reforms began, which is characterized by missions sent to the West in order to learn and then introduce the new sciences and advanced technology. Nonetheless, Western ideas and literature also found their way in through international relations and colonialism and changes were extended also to Islamic law.

These reforms were mainly done from above for and by the elite of these Islamic countries.

While in British India it was still necessary to abolish Koranic punishment, also called draconian punishments, hadd punishments, in countries belonging to the Ottoman Empire this particular law was reformed by a Muslim Caliph, regardless of the Shari'a. "The very first of these Ottoman qanun names ,that of Sultan Mehmmed II (1451-81) repeatedly refers to Islamic Law and freely uses its concepts. It treats, among other matters, that of penal law; it presupposes that the hadd punishments are obsolete and replaces them by $t a^{\prime}$ azir, i.e. beating, and/or monetary fines which are graded according to the economic position of the culprit."

The Ottoman Caliph also reformed commercial laws, with the Code of Commerce of 1850 , as well as the laws regarding the status of non-Muslim fellows. In 1856, under pressure from the French consulate in Turkey, the Dimma Status of non-Muslims was abolished. Already 'Abdul Mejid (1839-61), had declared non-Muslims for the first

8 Abdur Rahman I. Doi, Shari'a: The Islamic Law, London,1997, p.85.

9 J. Schacht, An Introduction to Islamic Law, p. 91. 
time "subjects" so that they were not longer called Dimmis or "protected subjects". ${ }^{10}$ However, the status would remain as a kind of unwritten law.

But it was first in Egypt that an intense intellectual activity was developed in the $19^{\text {th }}$.c. and $20^{\text {th }}$ century, trying to elaborate the law in accordance with Western law and practice. After independence of the Ottoman Empire in 1874, "Mixed Courts" were introduced and Shari'a began losing ground against Western law that took over. Most areas of law were modified according to Code Napoleon, even though some tenets of Islamic law were introduced or compatibility was eagerly sought. In 1920 a law book with 647 paragraphs on person and family law after the three main school of law ${ }^{11}$ was published. Codification of Shari'a law had begun seemingly with no return. ${ }^{12}$

The work done by the Caliphs in the Ottoman Empire and especially that done in Egypt became the corpus of law for the rest of Middle Eastern countries. In that way, a process of secularization of the law took place: "One legal subject-matter after another was withdrawn from the orbit of Islamic law."13

By the middle of the $20^{\text {th }}$.century, other reforms took place at the hands of the Egyptians. One year after the pact between England and Egypt, which guaranteed the independence of the country, the "Mixed Court" was abolished. The time for the nationalization of the law had come, ${ }^{14}$ and the law was taken under revision. The need to incorporate the Shari'a, as the spiritual inheritance of the country, was considered necessary for law giving. Shari'a had to be protected and used as a source for law giving. Still that would be done on the realm of the possible and having as criteria the law that had already been incorporated from the West. In fact, the claim was to take from the Shari'a what was possible to take, while the system remained basically based on a Western code of law. ${ }^{15}$

This re-elaboration or blending of Western law and Shari'a was accepted and incorporated by the rest of the Arab countries. Shari'a had always remained and continued to be applied in its most pure form only in the field personal, family and inheritance law.

An important date for the Islamic world had been that of the abolition of the Shari'a and the Caliphate by Ataturk in 1924. It was not by coincidence that the Muslims Brotherhood was founded in Egypt four years later, as the heirs of the true Islam and guarantors of the identity and continuity of the 'Umma. Their role will become prominent, as seen at present, especially after the new world order in the eighties.

10 J. Schacht, An Introduction to Islamic Law, p. 92.

${ }^{11}$ First Egypt had a codification of hanafi Law, the school of the Ottoman Empire. In 1920 the other two schools of law, present in Egypt were took into consideration for law giving.

12 Example is the Work in Arabic of al-Jaziri. "Islamic Law according to the four school of Law", still a work used today by jurists and 'ulama'. In Turkey Shari'a was first codified in al-Majalla in 1876-7, as the Ottoman Civil Code after hanafi school of Law.

13 J. Schacht, An Introduction to Islamic law, p. 92.

14 T. Nagel, Das islamische Recht, p. 307.

15 T. Nagel, Das islamische Recht, $\mathbf{p}_{1} 308$ 
Still, during the decade of the seventies in the $20^{\text {th }}$ century, there will be a process of reform in the area of family law, enacted by secularized Muslim governments in a period of secular leadership and values. We have an example in polygamy law in Egypt. Yihan Saddat, the first lady of Egypt, introduced reforms in polygamy law, so that women had to be informed in the event their husband took a second wife and she had the right to opt for divorce in that case. It has to be taken into consideration that women have very little rights to apply for divorce.

The secular period came to an end in the eighties. The triumph of the Iranian Revolution, the growing influence of the Gulf States, with the strict school of law, Wahhabism, and the new world order paved the ground for a major splitting up of Islamic countries from the West. With the Cairo Declaration of Human Rights in Islam in 1990, Shari'a became the source of legislation in all Islamic countries. Any law enacted in these countries could no longer contradict Shari'a law, at least in a theoretical way.

Muslims would no longer attempt to imitate the West, but on the contrary, to return to their tradition of Shari'a. Under the stronger political presence of Muslims Brotherhood and derivative groups, Shari'a became a slogan for identity and continuity, a slogan that assures the solution to all economic and political miseries, a slogan that gives hope to the new generation.

The question would be which Shari'a is aimed to and which are the methodological principles for deriving laws.

\section{The meaning and object of Shari'a.}

"In the two religions in which the law gained a central place-Judaism and Islam-(in the latter) law is presented in a particular light. In Islam, the law is already the central content of revelation." 16 :

Shari'a has been defined as a deontology17. Similar to Kant's deontology, the metaphysical question has been censured. Contrary to modern philosophy with its turn to the subject, Shari'a looks for the wellbeing of the community, 'Umma. So considered, Islamic society instead of being endangered by relativism, is rather to be feared of falling into totalitarianism. Whoever controls the religious Law has control of the people. Since the spheres of politics and religion are not well defined, any limits imposed by Shari'a to individual freedom are to be accepted as long as they are good for the 'Umma.

In a society where so many illiterate people exist and the elite tends to have an interest for practical sciences or Islamic knowledge, the question for the role of reason has not been seriously posed, even less than that of philosophical reasoning. Moreover, the scholarly tradition of 'ulama' considered philosophy as a heresy. Logic had been accepted as a useful instrument, but no place was given to ontology. For metaphysics is

16 The Law of God, University of Chicago Press, Chicago, 2008, p. 160.

17 R. Brague, The Law of God, p. 164. 
a question that goes beyond the capacity of human mind, therefore it is forbidden for men to enquire about it. 18

The relation between Islam, Shari'a and philosophy had not been a harmonious one. Reason has the function of conforming itself to the revealed Law. Indeed, reason should not question the content of law. "The question of the divinity of law is thus secondary in relation to that of the divine authenticity of Muhammad's mission." 19 Once the prophecy of Muhammad is accepted, by the same logic, law has to be accepted, asserts R. Brague. Revelation is given and rooted in transmission and tradition, without a systematic reflection under the light of reason. Theology, Kalam, is more an apology directed to prove the authenticity of the prophetic mission of Muhammad than to show the intrinsic value of the law or explaining faith through reason.

The authentic religious attitude is obedience to the law, which means obedience to God. To follow the ritual prayer and other prescriptions of Islamic law is what is expected from Muslims in order to get into paradise, God alone determines what is good and bad. He can order something to be considered as good, even though it is seen as something abominable by reason.

Al-Juwayni, Ghazali's teacher formulates this as the doctrine of orthodox Islam:

"The intellect does not indicate either that a thing is noble or that it is vile in a judgment that obliges, hukm al-taklif. It is informed about what it must consider as noble and as vile only by the resources of the law and by what tradition renders necessary. The principle of what must be said on the subject is that a thing is not noble by itself, by its genre, or by an attribute that belongs to it. It is possible that something may be noble for the law, while something similar to it and equivalent to it is vile according to all judgments of attributes of the soul." 20

No doubt, Islamic culture developed a complex and sophisticated system of law for its time. R.Brague mentions: "The quality of the law (...) could nonetheless be invoked as a proof of the superiority of the Koran over the other holy books." ${ }^{21}$ In that way, "Law became a powerful instrument in the hands of the emerging governing classes of Islam, which prevailed of melting itself into the conquered populations. A law of its own gave impermeability to the governing elite." 22

The fall of the Arabic Empire after the $11^{\text {th }}$ century made it even more necessary to rely on religious law, since the Caliphate had lost its credibility with the loss of actual power. Nonetheless, the Caliphate was formally preserved and Shari'a became the identity figure of the Umma, joined together with a de facto political power. For the sake of the survival of the Umma, political power was transferred to Turkish men and

18 Al-Gazali, Tahafut al-Falasifah, Pakistan Philosophical Congress, Lohore, 1963, pp. 1-3.

Ibn Khaldun, The Muqaddima, transl.F.Rosenthal, Princeton University Press, Princeton, Vol. III. pp. 246-50.

19 R. Brague, The Law of God, p. 161.

20 R. Brague, The Law of God, p. 166.

21 R. Brague, The Law of God, p. 164.

22 R. Brague, The Law of God, p. 147. 
Mongols, even if they were barbarians in the eyes of the cultivated Arabs and Persian population.

According to some jurists, after the $11^{\text {th }}$ century "the gate of ijtihad", or creative legal reasoning, had been closed. As a matter of fact, Islamic law and culture had stagnated from then on. Arabs complain that the decadence is due to the Turks, who invaded the Arabic Islamic Empire without adopting the Arabic language, in this way, not being able to keep with the achievements of Arabic culture. The period of imitation of previous juristic decisions, taqlid, began and continue until the encounter with the West, when part of the Shari'a had been abolished and Western law was introduced in Islamic countries.

Fundamentalists would revive the call for the Shari'a in the $20^{\text {th }}$ century with considerable success. Against the moral decadence in the West and neocolonialism, they claim Shari'a to be the solution. In fact, Shari'a has been presented as a utopia rooted in the first period of the history of Islam, which represents a time of complete harmony between politics and religion. This is a time to aim for, since it incarnates the pure and perfect life. In that sense, Islamic ideologies look backwards to an idealized period of history, that of the first centuries of Islam, as the guaranty for political changes and hopes.

Given that Islam proved itself through successful conquest at the beginning, both Muslim modernists and reformers of the $20^{\text {th }}$ century, like the Mufti of al-Azhar Muhammad Abduh, would affirm that the state of decadence in the Islamic world is due to the fact of not being good Muslims.

\section{The Islamic discourse on international human rights ${ }^{23}$.}

Liberal voices in the Islamic milieu defend the compatibility of Islam and human rights. However, these voices have diminished in the last thirty years. Secular political discourse has been silenced through the emergence of fundamentalists, which have taken great care to marginalize liberal intellectuals.

A widespread opinion is that human rights can only be fully realized under Islamic law. Only God gives rights to man and these are attached to their dignity by being Muslims. Dignity is founded in religion and in the belonging or proximity, being the case of Jews, Christians and Zoroaster, to the religion of Islam. Religion, being intermingled with a social and political organization, defines the dignity of the person. This conception is expressed in the Shari'a especially regarding the status of non-Muslims, who enjoy partial rights or no rights at all, in case they have a pact-Dimma pact- or do not have any pact-harbi-.

A different case is that of women. Since given rights are dependent on duties and responsibilities in social life, women will have equal dignity as men in front of God, but different rights, due to their different tasks in life.

23 Mashood A. Baderin, International Human Rights and Islamic Law, Oxford University Press, N.Y.2003, p. 13-5. 
A more aggressive discourse against human rights asserts that international human rights are an imperialist agenda and must be rejected. Human rights are identified as a civil religion that pursues the destruction of Islam in the same way as it has done with the Church in western societies. This anti-religious agenda is based in the idea of separation of religion and state.

Nonetheless most Muslims are not against international human rights but complain of the double standard of the West, since the Universal Declaration of Human Rights in 1948 coincides with the creation and recognition of the State of Israel and deprivation of Palestinian Land.

The issue of Human Rights has become in general highly political, and less a question to consider and reflect on, in order to reach a judgment. The theoretical question on the foundation of human rights has been treated by some Islamic Scholars from different perspectives. Traditional scholars see the basis of human rights in the Koran. Others try to prove the origin of international human rights in Islam, tracing the way back to the end of the Middle Ages, when Islam influenced the West and became part of its heritage. In that way "P. Bellow, Ayala, F. de Victoria would have been influenced by Islam during the period of the Renaissance through the transverse of knowledge from Islam into Spain and Sicily."24

At present, the question of human rights in developing countries and especially in Islamic countries is discussed on the basis of cultural relativisms or the question of universality versus universalisms.

In the West there are those who see the origin of human rights in the tradition of natural law. Others, for their part, see it in the political experience of western civilization and History of positive law, without reference to natural law.

This last position tends to be a relativist one, denying the possibility for knowing absolute and objective values. The concept of dignity of a person, even the most basic concept of person is put in question and left to be defined by cultural, social, political consensus or the consensus of experts. The will of a lobbying group working with "experts" will define what belongs to another sphere of knowledge.

Against the opinion that there are universal values and rights to be recognized by all as expressed in the Declaration of Human Rights, there is the position of criticizing western universalisms, which is seen as an ideology. In that sense, international human rights should, in the opinion of Muslims, recognize the values and richness expressed in the Shari'a, which, not to mention, is for Muslims of universal value.

Still within this discourse, it is said that if the Declaration were presented today to be signed, there would be no general acceptance on the part of developing countries. Cultural inferiority is not acceptable anymore. Developing countries have gained selfconfidence and will not let the West intrude in their cultures on the basis of a neocolonial political weapon called universal human rights. From the beginning, SaudiArabia, anchored in a traditional society and with enough self-confidence, did not rec- 
ognize human rights because of the articles on equality of men and women and religious freedom.

Subsequently, and parallel to this political discourse, we have the Cairo Declaration of Human Rights in Islam, that was signed by the States of the Islamic Conference in 1990.

Some passages shed light into the Muslim perspective on Human Rights and Is$\operatorname{lam}^{25}$ :

"Reaffirming the civilizing and historical role of the Islamic Umma which God made the best nation that has given mankind a universal and well-balanced civilization in which harmony is established between this life and the hereafter and knowledge is combined with spiritual faith; and the role that this Umma should play to guide humanity confused by competing trends and ideologies and to provide solutions to the chronic problems of this materialistic civilization.

Wishing to contribute to the efforts of mankind to assert human rights, to protect man from exploitation and persecution, and to affirm his freedom and right to a dignified life in accordance with the Islamic Shari'a.

Convinced that mankind which has reached an advanced stage in materialistic science is still, and shall remain, in dire need of faith to support its civilization and of a self-motivating force to guard its rights.

Believing that fundamental rights and universal freedoms in Islam are an integral part of the Islamic religion and that no one as a matter of principle has the right to suspend them in whole or in part or violate or ignore them in as much as they are binding divine commandments, which are contained in the Revealed Books of God"

Article 10 states: "Islam is the religion of unspoiled nature (fitra). It is prohibited to exercise any form of compulsion on man or to exploit his poverty or ignorance in order to convert him to another religion (apart of Islam) or to atheism."

Article 10 makes freedom of religion not only impossible but it also expresses the concept of "nature in the religion of Islam. There is not a given common nature to every person that confers its dignity upon a person as such; it is the belonging to the religion of unspoiled nature, Islam, which confers dignity upon the person. In that sense, non-Muslims do not enjoy the same dignity as Muslims, according to the Shari'a.

\section{Conflicting points of Shari'a and international human rights.}

As it has been mentioned before, Islamic culture developed a complex juridical system in the Middle Ages and defined itself through the law. We find in the Koran and Sunna the principles and duty of safeguarding the right of life, property, family, upright mind and religion. These rights can only be fulfilled in a complete way in the Umma, the community of Muslims. For the law is characteristic and identity factor of a people to whom God revealed it. Each religion has its own law, says Ibn Khaldun in al- 
Muqaddima, and since Islam is the only religion with a universal mission, religion and politics are united. ${ }^{26}$ Here it is to be observed that religion and law are used as synonyms and as such the mission of expanding religion requires and makes it necessary to include expansive politics.

This conception of Shari'a is already conflicting with human rights. More specifically, there are four main fields of law conflicting with international human rights:

1. Koranic punishment.

2. Women's rights.

3. Relation to Non-Muslims.

4. Freedom of conscience and speech.

\section{Koranic punishment or hadd punishment.}

They are so called, because these five offenses are explicitly mentioned and forbidden in Koran. Since they are found in the Koran, it is considered to be within the realm of God's rights and they have a religious character. In fact, they were often used as measures of military discipline. However, since they are found in the Koran, no one can diminish the punishment for the crime, change it into a discretional punishment, abolish or modify them.

However, modernity had brought about the abolition of hadd-punishment in many countries, either at hands of the Ottoman Caliphs or under the influence of Western culture and colonialism.

The Koranic punishment is applied in case of five kinds of offenses:

1. Adultery and fornication. The punishment is different for adultery and for fornication or sexual intercourse of non-married people. Adultery is punished by stoning or crucifixion, and the latter case by a hundred lashes. That will suffice since it is understandable, that young people fall in the trap of necessity or curiosity.

In both cases, four male eye-witnesses, with legal credibility, are required to establish proof. Moreover, it has to be proved that the act was voluntarily done. That makes it almost impossible to establish proof. For that reason Muslims see koranic punishment as something seldom to be applied.

A modern jurist, Shalabi, "points out that the proof required makes the punishment only applicable to those who commit the offence openly without any consideration to public morality". 27

2. False accusation for adultery, which is punished with eighty lashes. This is found in Koran 24, 4., possibly having its origin in a false accusation raised against Aisha, Muhammad's wife. ${ }^{28}$

26 B.1, pp. 320-22.

27 M. A. Baderin, International Human Rights and Islamic Law, p. 80.

$28 \mathrm{~J}$. Schacht, An introduction to Islamic Law, p, 175 
3. Theft is punished by amputation of a hand and each consecutive time with cross-amputation of foot and hand. The thief has the opportunity to recant his crime by returning the stolen object before the crime is brought before the court. In this case, the Koranic punishment will not be applied. In addition to that, the stolen thing should amount to a certain value for the Koranic punishment to be applied.

4. Rebellion or armed robbery is punished by crucifixion, cross-amputation of the hand and foot or banishment.

5. Intoxication, mainly through drinking alcohol, is punished with forty or eighty lashes, depending on the law school and it has to be proved that it happened voluntarily.

The sixth crime punished by means of Koranic punishment would be that of apostasy, which requires the death penalty. However, some modern jurists consider apostasy not within the realm of Koranic punishment, but as an issue to be left for the afterlife, to be punished by God. Hence, it should not be punished by death, unless it reaches the category of rebellion against the State. But this topic will be dealt with under the question of religious freedom.

Besides the crimes and punishment established in the Koran, penal law in Islam has its foundation in the law of vengeance, talion. This chapter of law belongs to the realm of men, to their rights. For that reason, it can be exchanged or not applied, even in the case of murder, if the contending parties reach an agreement. In case of intentional killing, the life of the murderer could be saved by paying blood money, if the family of the victim agrees that life should be spared. Then the criminal will be put in prison after having paid blood-money.

In case of offences like having been wounded, the same kind of wound should be inflicted upon the criminal, unless the victim decides to forgive.

The justification for these disproportionate punishments is that they a deterrent for society. However, there is a kind of utilitarian conception of justice, when it is argued, that the disproportionate punishments are almost not applied and affect a minimum of people. This contradicts the idea of justice that implies that the value of each and every member of society is equal and infinite. A single transgression of justice done through a disproportionate punishment, even if it is for utilitarian reasons, is injustice.

\section{Women's rights.}

We can gather together the conflicting women's issues as follow:

Polygamy, the right of man to punish his wife, marriage of infants girls, compulsory marriage, compulsory dress, strict separation of genders, no right to keep their children in case of divorce or becoming a widow, no rights to ask for divorce against the unlimited right of a man, inequality by inheritance, no possibility for a woman to marry a non-Muslim, compulsory divorce in case man commits apostasy.

The Koran 2,228 and 4, 34 are verses that speak about the rank of women. The Koran 2,228 says in a context of the law of divorce: 
"Divorced women shall wait concerning themselves for three monthly periods. Nor is it lawful for them to hide what Allah hath created in their wombs (...) And their husbands have the better right to take them back in that period, if they wish for reconciliation. And women shall have rights similar to the rights against them, according to what is equitable; but men have a degree (of advantage) over them."

Koran 4, 34 says:

"Men are the protectors and maintainers of women, because Allah has given the one more (strength) than the other, and because they support them from their means. Therefore, the righteous women are devoutly obedient, and guard in absence what Allah would have them guard. As to those women on whose part fear disloyalty and illconduct, admonish them(first), (next), refuse to share their beds,(and last) chastise them (lightly)."

These are the verses used to legitimize the submission of women to men and the right men have to chastise women physically.

In a historical context these verses could be easily interpreted as an expression of a patriarchal society that has become obsolete at present. However, since the Koran is the word of God it is difficult to declare them as obsolete. It will depend on the education of man, the social class, and character, if they will make use of or not of the Koranic allowance to chastise their women.

The verse allowing polygamy in the Koran has its origin in the restriction given to a tribal society to limit the number of wives to four. With new economic conditions, especially in the cities, polygamy is not as wide spread as it is used to be.

Moreover a popular opinion among some Muslims is that de facto polygamy is prohibited, since the Koran demands a just treatment of all wives and this is completely impossible to fulfill. Nonetheless, the most accepted opinion is that polygamy is necessary in extreme cases and for that reason should not be prohibited.

These cases are as follow:

- When the woman is sterile, she cannot have any children or produce male descendant.

- When the wife becomes ill or old, and cannot fulfill her wifely obligations.

- When woman have behaved badly.

- When the man has an extraordinary sexual need or drive.

As a matter of fact, polygamy is predominantly found in the countryside, where a big family means having the necessary hands to work the fields. A different kind of polygamy is that of the upper-class. Here polygamy is a symbol of status and male fulfillment.

Muslims support the argument for the legality of polygamy by saying that legalized polygamy is better than having illegitimate relations, as in Western society. Muslims consider Islam as the religion of the just-middle, the middle between two extremes, that of Atheism and of Christianity. Therefore, polygamy would have the function of keeping up with "reality", fulfilling a need and even lowering the level of suffering and burden for people and society. 
However, observing this perspective, these considerations point to a kind of utilitarian morality, where the value of each and every single person does not count, but it counts rather the principle stated by J. Bentham: "the greatest happiness for the greatest number".

Modern family law has introduced reforms to classical Islamic law so that in some countries men need the permission of the court to take an additional wife. The court will examine if he has the required material means to support a second wife and that the first wife is informed of the intentions of the husband. In Egypt, for instance, the first wife would have the option to apply for a divorce in this situation, where Islamic law normally would not allow it.

In 1924 and 1956 respectively, polygamy was abolished in Turkey and Tunisia. In spite of the fact that it is punishable by imprisonment and a fine, the practice as a long grown tradition has continued in these countries, showing that Shari'a has indeed a higher authority than the law of the state. Recent voices in Tunisia have called for reintroducing polygamy, as a fulfillment of the idea of a country conformed to Islam.

Other points in Shari'a on women's right are as follows:

- Child marriage is legal according to the Shari'a. Women are given for marriage when they are nine or ten years old which is the age of sexual maturity or adult age according to classical Islamic law. This law can lead to the actual selling of young girls by their parents in order to manage a difficult economic situation. However, modern reforms have been occurred in most countries, stating the age of maturity to 16 and 18 years old.

- A compulsion to marry can also be inflicted upon adult women. A woman needs someone to represent her to conclude the contract of marriage, exception in hanafi law, and this person usually is her father or a close male relative. A mute answer or silence, when ask if she accepts her partner, is interpreted as a sign of approval according to Shari'a. Maliki law approve compulsory marriage, if the marriage have been arranged by the father of the bride. He is not obliged to ask her opinion.

- Within marriage, a woman enjoys different rights than a man. For instance, children belong to the family of the father. According to classical Shari'a, in case of divorce the woman has the right to have the children until the age of 7 for males and 12 for females. Reforms in modern times have provided in some countries that the mother could keep the girls till they get married while boys belonged to the father. In the case of a non-Muslim mother, children belong to the family of the father in all instances. If divorce occurs or she becomes a widow, the mother only would have the right of nourishing the baby till the age of two. This is justified on the basis, that the mother would educate the child in the wrong religion.

- Another controversial issue is divorce. Divorce is a right of a man, who can repudiate a woman without mentioning any reason for it. In classical law, and today if an Islamic marriage has not been registered, the man does not need to go to court to obtain a divorce. It will be enough to swear three times before two witnesses in order to obtain a legal divorce.

In contrast, women can request a divorce in only few and extreme cases: 
- When the man cannot sustain the family economically

- When he disappears for a long time or is in prison for life

- If he becomes mentally ill

- If he is impotent

- If he uses extreme violence against her

- Another resort is when a man agrees to the petition of divorce of his wife, khulu', in this case she has to pay the dowry back.

- Compulsory dress and strict separation of gender is derived of the concept of the relationship between man and woman. However, the veil has become more of a political issue than of a religious one in modern times. In some countries, like Iran, the veil is prescribed by the state. In other countries it is still optional although the social pressure is strong, to the point of being a condition for employment in some companies or institutions.

Few women view the veil as an expression of their relationship with God. The veil is a demonstration of identity and belonging. Women wear it sometimes due to pressure by their male relatives and sometimes it comes from their own political consciousness. On the contrary, the burqa is not a Koranic prescription, but a religious recommendation for those that voluntarily would like to fulfill it.

The veil in the Koran is given as sign for the righteous women to be respected by their Muslim men. Koran 33, 59 mentions:

"Oh Prophet! Tell thy wives and daughters, and the believing women, that they should cast their outer garments over their persons: that is most convenient, that they should be known as such and not molested."

This implies that non-veiled women are to be considered non-respectful ones in conservative circles. The status of a woman in general is given by the status of her family and the protection that the family can provide for her.

\section{Relation to Non-Muslims.}

We find a kind of first draft of international law in Islamic law regarding the issue of relation with non-Muslims. The laws of war and the rules regarding the way of dealing with non-Muslims were already developed in classical Shari'a. Here, we find humanitarian laws, i.e., the killing of civilians was forbidden by law, and that includes the killing of women, children, elderly and ill people as well as monks.

Traditionally, Islamic law divides the world in Dar al Islam, the House or Territory of Islam, and Dar al-Harb, the Territory of War. Later on, it was developed the concept of Dar al-Sulh, the territory of Pact.

Relations with non-Muslims are normally addressed at the end of a Shari'a book, under the title and chapter on Jihad.

The relations with non-Muslims outside the Territory of Islam are a belligerent one in classical Shari'a, unless a Pact, Sulh, has been signed. In the case of Iran today, they consider countries having diplomatic relations with Iran as Dar al-Sulh. Those countries without diplomatic relations are considered Dar al-Harb. Citizens of Dar al-Harb 
do not have any rights, including the right of protection of their lives, if they enter Iranian territory.

A temporary permission to enter and practice an activity in Islamic territory, mainly commerce, was already provided by law in the Islamic Middle Ages. Permanent residency, however, would not be allowed in Islamic territory to non-natives nonMuslims, unless by marriage, according to Shari'a.

The status of non-Muslims living permanently in Islamic territories dates from the time of the conquest and is called Dimma Status. The Dimma Status has its origin in a war pact, by which non-Muslim subjects agreed to recognize the dominion of Islam and pay extra taxes in exchange for having their lives and property protected and permission to practice their own religion within certain restrictions. The pattern and origin of this pact is that of a victorious nation over a submitted one.

The relation to Non-Muslims living permanently in a Muslim country, according to the Shari'a, is a relation between a submitted nation and a victorious one. The basis for the status of Non-Muslim living permanently in Islamic territory, called Dimma Status, or status of protected people, goes back to a pact sign up by the Caliph 'Umar b. alKhattab. This contract is transmitted in different forms in different juristic works, from a soft version in K. al-Kharadj of Abu Yusuf in the $8^{\text {th }}$ century, until the last known version in the $12^{\text {th }}$ century by al-Turtushi. These pacts reflect the status of Non-Muslims in different periods of Islamic history.

The Dimma status provides, according to the Shari'a, for the protection of life, property and restricted religious practice in exchange for the recognition of Muslim rule and the payment of extra taxes by each adult male, with exception for the ill, elderly men and monks.

Islam entered the Christian territories of the Middle East and established itself as a military rule. Nothing changed at the beginning and the social structure remained apparently intact. The Umar Pact reflects how Muslims believed that the Dimma status would be a temporary one. Consequently the population had the right to keep their churches and synagogues, but not to build new ones. They were also committed to help Muslims in war, give them lodging, and help them to build bridges. Insulting Muslims, hitting them or serving the enemy as spies or denouncing their weak sides was prohibited. Carrying and having weapons was forbidden for them. Bells were not supposed to sound during or before the Muslim prayers and processions were limited to once a year

Al-Turtushi in the $12^{\text {th }}$ century adds more of these restrictions. Churches and synagogues are not to be restored. Proselytizing and incitement to apostasy from Islam is strictly forbidden, but any conversion to Islam should be not hindered. Non-Muslims should not sell alcohol or have a direct view over a Muslim house. Processions were forbidden as well as the public display of crosses and sacred books. Bells were supposed to ring quietly. Separate forms of dress were required for non-Muslims, so that non-Muslims could be distinguished from Muslims. Muslims were to be treated with respect, been given priority to sit, if they wish to sit down and be greeted first.

These conditions have not always been applied in the same way in all periods. Nonetheless, some of them have always been enforced in all times and periods, like the 
law concerning the building of temples. Other laws have been temporarily applied, when required. Some of these rules have been kept in Muslim secularized society in modern times as unwritten laws, like that of non-Muslim.

The Dimma status had been abolished in the Ottoman Empire under pressure from the West, meaning with that the abolishment of extra-taxes. However, remnants of the Dimma status endured in written or unwritten laws. It remained extremely difficult to build temples and their de facto status continued to be that of second class citizens, with exception of the colonial era, and especially when the Christian elite played a key role in the modernization of society.

The conception and pattern of a nation living under the rule of another nation has still not disappeared at an official level in Islamic society. This pattern had been a pragmatic solution of Islam in its conquering period in order to incorporate quickly a vast amount of territory. This pattern of Dimma status is previous to the creation of national states and conflicts in many aspects with it. Under this form of organizing the state, it is conceivable that a people can live separately from the Muslim population in their own cities or areas, having their own system of family law and personal status and still belong to Muslim territory. Even if it was conceived to be a temporary situation, the Dimma status has however remained in society for centuries to the present days.

The concept of equal rights, especially political rights for non-Muslims, does not exist according to Shari'a. Man does not innately possess a nature and dignity per se; this is given by a religious belonging to Islam. Christians and Jews as well as Zoroastrians have a certain dignity because of their proximity to Islam, so that they can become dimmis or protected people. Atheists, on the other hand, have very little dignity according to the Shari'a. They are expected to convert to Islam. For that reason, Muslim men may marry a member of these three religions, but not an atheist. An atheist woman must to convert to Islam.

Other discriminatory rules are found in the Shari'a for non-Muslims men and women. A non-Muslim cannot give witness in court against a Muslim.

If blood money has to be paid, because of an accident or murder, the life of a nonMuslim man is worth half of that of a Muslim, a non-Muslim woman only a fourth of a Muslim man and half of that of a Muslim woman. In case of inheritance, non-Muslim women will not inherit from their Muslim men, even if they become widows.

\section{Freedom of religion and speech.}

It has been mentioned before that some jurists consider apostasy to be one of the Koranic punishments. Meanwhile, a few other jurists, following a modern trend of thought, consider apostasy as a sin to be punished by God in the afterlife.

Apostasy could indeed be compared with the offense of high treason from the perspective of classical Shari'a. Since the 'Umma is a political-religious community, to leave the community is not only an issue of being punished by God in the afterlife, but it is to be punished with the death penalty. An indicator that there is a political conception underlining the punishment for apostasy is the fact that men are to be punished in all cases with the death penalty while women, depending on the school of law, are not. 
They are usually imprisoned and beaten to secure a change of opinion. Jurists justify the punishment on the basis that a man can make war and fight the 'Umma. In becoming an enemy of the community, he is more of a threat for the stability of the community than a woman and he should be eliminated since he commits rebellion. In either case, both men and women have three days to repent and be considered Muslims once again, and no punishment will be administered.

The origin of this penalty is to be found in the Ridda or the Wars of Apostasy. As a measure against deserting the troops of Islam, desertion was prevented by punishment for the crime for apostasy.

Liberal Muslims jurists try to place the punishment for apostasy in the afterlife. However, this opinion is not widespread, since the question of the allowance for departing from the true religion, from goodness, is made.

At present, after the reforms of Shari'a and the legal system, most Westernized Islamic countries penalize apostasy with prison or exile. ${ }^{29}$

Some moderate Muslim jurists assert that if a conversion is made in private and it does not represent a threat to the Islamic community, the person should not be punished. This means, that the person must not be a public figure and any conversion has to be done in secret. ${ }^{30}$

A non-Muslim who has insulted Islam or Muhammad will be also condemned to the death penalty and their only course of escaping punishment would be conversion to Islam. In this situation, Shari'a considers that this person has lost the Dimma status that provides protection over life.

In both cases, apostasy and losing the Dimma status, appear in modern times under the same label, that of Blasphemy Law. Blasphemy law is a modern appellation for apostasy and the prohibition for Non-Muslims of insulting Islam and Muhammad, by which they lose their status as protected people, Dimmis.

Both cases point out the challenge posed by Islam to freedom of religion and personal freedom. The difficulty of acknowledging freedom of religion in Islam has its origin in the fact that Islam is given genealogically to the children; a child of a Muslim father is by law a Muslim. In addition to that, abandoning the "true religion" or not choosing goodness is not justified to the eyes of Muslims. Human nature is predisposed to be Muslim, according to the Shari'a. Only the parents divert their children into a different religion or non-religion. The concept of original sin does not exist in Islam,

29 This is the case of Abu Zayd, scholar from Egypt, who had to leave his country in 1994 because he was charged of heretical interpretation of the Koran and Shari'a. His wife was compelled to divorce him, although she was able to escape the country. The charge was brought to court by a traditionalist of the official institution for Islamic Affairs, al-Azhar.

30 When Magdi Alam, an Egyptian and Muslim journalist living in Italy, was baptized by the Pope on Easter Night of 2008, al-Azhar issued and statement against the public character of this baptism, for it would be better if he had been baptized in private. In this case, the person was beyond the jurisdiction of Islam, and Sunni law, different from Shi'a one, does not allow persecution of apostates outside the borders of Dar al-Islam. However, fundamentalists threaten the journalist. 
therefore is found the conception that the Shari'a guides and guarantee nature to reach its pure and natural state.

In that sense, Sayyid Qutb, the great theoretician of the Muslim Brothers, in referring to a verse in the Koran, "there is not compulsion in religion", explains that since everyone is Muslim by nature, there will be no compulsion in religion if someone is obliged to become a Muslim.

\section{Excursus: Jihad. Violence in a religion of the $21^{\text {st }}$ century?}

Jihad literally means effort, to fight (to make effort) in the path of God. The word is usually used, in the context of fighting "on behalf of God".

Classical Shari'a classifies Jihad in two forms:

Small Jihad, with the meaning of war, and big Jihad, understood as asceticism.

The ascetical meaning is especially found among Sufis. It is often aimed for those who prepare themselves for war.

Other types of Jihad are that of Jihad of the word, on behalf of the mission of Islam and monetary Jihad, meaning to provide the means for that mission.

However, the question of Jihad is not whether Muslims as such are violent or if their society is of a violent nature. This is an erroneous and an inaccurate question. The correct question is if Islam, as a system of social organization, may contain an element of violence given by an anachronistic law, that of classical Shari'a.

From a historical perspective, Islam was an Empire or, in modern terminology, a colonial power, during the middle Ages. Politics and religion, both sacred and profane, were together from the beginning. Muslims assert that, the first era of Islam, during the time of Muhammad and that of the four rightful caliphs is the period when a complete harmony between religion and politics existed in History. Thereafter, political power became corrupt in the struggle for power and dominance of different groups and families.

Real politics gained ground. The decadence of the Arab Empire began in the $11^{\text {th }} . \mathrm{c}$, and political power was transferred to those who had military power, the Turks, after a formal recognition of Islam. Thereafter, Jihad continued to be waged by the Ottomans, as successors of the Arab Islam.

Given that Islam brings together the sacred and profane sphere, and has proven itself by building an Empire, there is no principle, historical example or dogma that allows it to declare Jihad as an obsolete concept.

Nonetheless, it must be taken into account that Jihad as a religious obligation, fard kifayya, is not meant for everyone, but for a certain number of people in the community. The rest of the people assume the obligation of jihad only when no one fulfills the commandment or it is required by the Caliph, in case of great danger for the 'Umma. Therefore, Jihad could be compared with the concept of an Army obliged by religious law to constitute itself.

In classical Islam, Jihad was recalled and waved by the Caliph, Sultan or ruler. Indeed, it is a modern phenomenon that Jihad is invoked by groups with no political 
functions, in the form of people movement, or as a movement fighting for social and political rights.

Fundamentalism originated as a result of the abolishment of the Caliphate in 1924 by Ataturk. By no coincidence the Muslim Brothers were founded in Egypt in 1928, four years after the caliphate and the Shari'a had been abolished by Ataturk. They saw themselves as the true heirs of Islam, the one who preserved and guaranteed identity and continuity to the Islamic 'Umma.

The element of violence in Islam is found at a political level, justified by a religious tradition where the profane and sacred is not separated and clearly defined and where dogmas and historical examples cannot help.

However, it is necessary to distinguish between a political system anchored in a history of building an Empire on the base of religious belief and the population as well as particular individuals. When the population, mostly illiterate, gets involved in violence, it happens often because of manipulation by certain political factions.

\section{Conclusion}

The period of secularization of the first part of the $20^{\text {th }} . c$ until the seventies, has come to an end in the Islamic world. Equal rights and freedom remain a challenge for Islam, as long as the legalist tradition of classical Shari'a remains. Reforms have taken place in modern times in Islamic countries and these reforms also affected the Shari'a. Appreciation for the value of freedom and the use of reason are part of Islamic societies in one way or another. Some conservative groups, fearing to follow the path of moral decadence of the west, hold on to values of their own religious tradition. Political groups, however, use the just demand of the population for moral values and social justice, for their own interest. The claim for Shari'a becomes an instrument of control and manipulation when freedom is not taken into account. In this case, the rights of the population, Human rights, are not considered and Shari'a might be used to limit the freedom of individuals on behalf of the interest of the community.

On the other hand, the west does not have all the answers or the right to impose ideas or political systems on others. As a matter of fact, the danger of a relativistic interpretation of Human Rights that could revert against western society itself is real, if the foundation on which they rest is forgotten. Although Human Rights apparently are well accepted in the west, the extreme individualism and relativism of a self-centered society may well result in a back lash.

A blending of western and Islamic ideas, institutions and way of life has already taken place in the Islamic word in the last century. Globalization is a fact that challenges everyone to open up and achieve more solidarity. It is a task for everyone to deepen the own tradition under the light of reason and good will in order to search for the roots that binds the human family together. 